
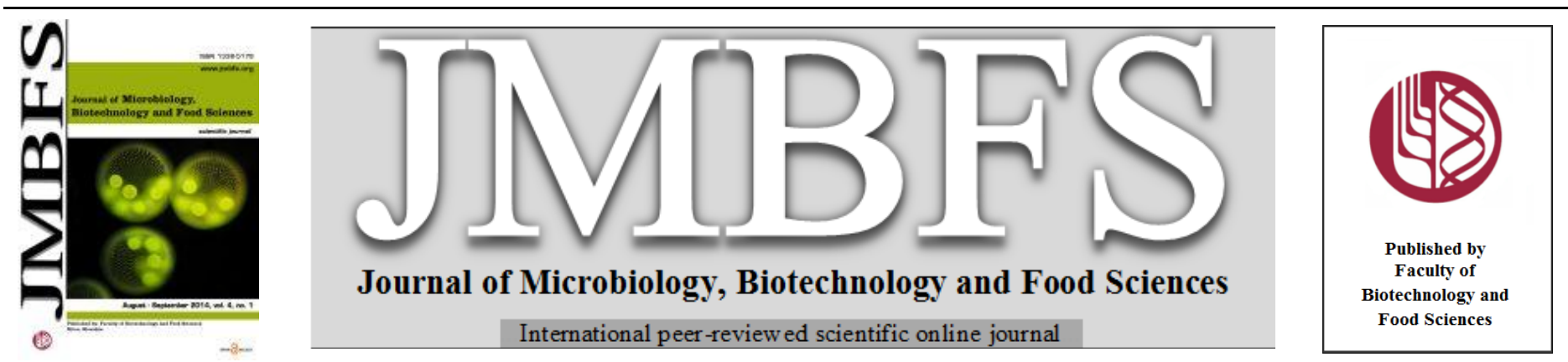

\title{
IDENTIFICATION AND BIOLOGICAL ACTIVITY OF POTENTIAL PROBIOTIC BACTERIA ISOLATED FROM POECILIA RETICULATA (GUPPY)
}

\author{
Aparna Balakrishna
}

Address(es):

School of Biosciences, Mahatma Gandhi University, Priyadarsini Hills P.O., Kottayam- 686560, Kerala, India.

*Corresponding author: aparnabalakrishnaa@gmail.com

doi: $10.15414 /$ jmbfs.2014.4.1.83-87

\section{ARTICLE INFO}

Received 16. 7. 2013

Revised 10. 7. 2014

Accepted 14. 7. 2014

Published 1. 8. 2014

Regular article

open $\partial_{\text {access }}$

\begin{abstract}
Antagonistic activities against candidate indicator strains, adhesion to mucus and biofilm formation of potential probiotic strains isolated from Poecilia reticulata were evaluated. Four isolated strains (MBTU_PB1, MBTU_PB2, MBTU_PB3 and MBTU_PB4) showed moderate to strong antagonistic activities against the tested five indicator strains (Aeromonas hydrophila1739, Vibrio cholera 3906, Flavobacterium 2495, Acinetobacter 1271 and Alcaligenes 1424) and these isolates were further identified using biochemical tests and 16S rDNA gene sequence analysis. Except the whole cell product, the other three cellular components, namely, heat-killed whole cell product, intracellular product and extracellular product of all the four selected isolates were equally effective, as revealed by the zone of inhibitions to the tested indicator strains. The in vitro adhesion property or the ability of colonization is often considered as a selection criteria for probiotics. All the selected four strains had higher adhesion abilities than the indicator strains. Further, these four strains had the ability to form biofilms on polystyrene surfaces. The in vitro characterization of these four strains suggests possibility of using the isolates, as individual strain or in combination, for probiotic therapy in aquaculture.
\end{abstract}

Keywords: Antagonism, cellular components, probiotic, adhesion, biofilm

\section{INTRODUCTION}

Aquaculture is rapidly increasing globally and it has a significant economic importance. However, protection of farmed fish from various diseases, especially in early stages of their life, is a prerequisite for increasing production and further development of aquaculture. Combined with the problem of antibiotic contamination of aquaculture facilities and livestock, the indiscriminate worldwide use of antibiotics in aquaculture has led to the development of drugresistant bacteria that are becoming increasingly difficult to control and eradicate (Bruun et al., 2000). An alternative disease prevention method that involves the use of non-pathogenic bacteria as probiotics is proposed (Austin et al., 1995) Probiotics is generally defined as viable micro organisms that when applied to human or animals, beneficially affect the health of the host by improving the indigenous microbial balance (Fuller, 1989). A good pool of candidate probiotics is of importance in the development of commercial probiotics in aquaculture. Bacteria in aquatic ecosystems might produce antimicrobial substances inhibiting the growth of other microorganisms (Giri et al., 2011). Selection of potential probiotic strains is based on many different criteria, such as acid and bile tolerance (tolerance to gastrointestinal environment), antagonistic activity against pathogens and survival in gastric juice.

Adhesion of probiotic microorganism to the intestinal mucosa is considered important for many of the observed probiotic health effects. Adhesion is regarded a prerequisite for colonization in fish intestinal tract, antagonistic activity against enteropathogens, modulation of the immune system and for increased healing of the damaged gastric mucosa (Ouwehaand et al.,1999). In nature, the bulk of bacterial biomass is believed to exist as an adherent community of cells called a biofilm. A well-established biofilm of probiotic bacteria might prevent the proliferation of fish pathogenic bacteria, e.g., Roseobacter 27-4 showed high adhesion capability and formation of biofilm under growth conditions, which facilitates its production of an antibacterial compound, tropodithietic acid (Bruhn et al., 2005). Adhesion is the capture and/or entrapment of cells in a biofilm. This refers to the interaction of the bulk liquid (mucus) compartment components with the biofilm components, which in contrast to adsorption, occurs at the liquidsubstratum interface (Characklis et al., 1990).

The use of probiotic is an important management tool, but its efficiency depends on understanding the nature of competition between species or strains. Antimicrobial activity is thought to be an important means for probiotic bacteria to competitively exclude or inhibit invading bacteria. We recently reported the isolation and selection of potential probiotic bacteria from the natural flora of guppy based on their production of antimicrobial substances (such as, bacterocinlike inhibitory substances), antibiotic sensitivity tests, plasmid profiles and in vitro growth characteristics like lag period and doubling time (Balakrishna and Keerthi, 2012; Balakrishna and Kumar 2012; Balakrishna 2013). Potentia probiotic bacterial species differ in terms of their bioavailability, metabolic activity and mode of action. However, to be used in host-associated activities, they all must be non pathogenic and non-toxic. In addition, probiotic bacteria must survive the transition to the target niche and then persist, serving to protect the host against infection by pathogenic microorganisms. To address these related issues, four potential probiotic strains from guppy identified at molecular level was studied for their probiotic properties such as in vitro antagonistic activity of the cellular components and adhesion to the fish mucus. Furthermore, the selected isolates were tested for their ability to form biofilms.

\section{MATERIAL AND METHODS}

\section{Bacterial strains}

Forty six bacterial isolates were collected from the skin, gill, gut, and intestine of common guppy, Poecilia reticulata (from Kerala, India) using serial-dilution plating method in nutrient agar. Five bacterial strains (Aeromonas hydrophila 1739, Vibrio cholera 3906, Flavobacterium 2495, Acinetobacter 1271 and Alcaligenes 1424) pathogenic to guppy were used as indicator strains (standard cultures collected from Microbial Type Culture Collection (MTCC) Chandigarh, India). Four of the isolated strains, namely, MBTU_PB1, MBTU_PB2, MBTU_PB3 and MBTU_PB4 (Balakrishna and Keerthi, 2012) were studied in detail for its antimicrobial substances.

\section{Antimicrobial activity assay}

The antibacterial activitiy was assessed against the five indicator strains using agar disc-diffusion method (Balakrishna and Keerthi 2012). To obtain the cell free supernatant (CFS), the bacterial isolates were inoculated in tryptone soya broth (TSB) and allowed to incubate at $37^{\circ} \mathrm{C}$ for $36 \mathrm{~h}$ on an orbital shaker at 120 $\mathrm{rpm}$. The samples were centrifuged at $12,000 \mathrm{rpm}$ for $15 \mathrm{~min}$ at $4{ }^{\circ} \mathrm{C}$ and the supernatants were filtered through $0.22 \mu \mathrm{m}$ filters using a sterile membrane filter assembly. An aliquot of $50 \mu \mathrm{l}$ of the resulting CFS was applied to $6 \mathrm{~mm}$ sterile discs (Hi Media) on Müller-Hinton agar plates previously swabbed with the 
suspension of indicator strains. The plates were incubated at $37{ }^{\circ} \mathrm{C}$ for $24 \mathrm{~h}$ to record the zone of inhibition around the disc.

\section{Bacterial identification}

All the four isolates were identified using bio Mérieux VITEK 2 compact system (Version 03.01 software) identification cards as well as 16S rDNA gene sequencing. The bacterial genomic DNA isolation of the samples was performed following the procedure of Sambrook $\boldsymbol{e t}$ al. (1989). Polymerase chain reaction $(P C R)$ amplification was carried out with universal bacterial primers: forward, 5'-AGA GTT TGA TCC TGG CTC AG-3'and reverse, 5'-GGT TAC CTT GTT ACG ACT T-3'. The sequence of the insert was determined using the automated DNA sequencer. The basic local alignment search tool (BLAST) program (www.ncbi.nlm.nih.gov/blst) was employed in order to assess the degree of DNA similarity. Multiple sequence alignments and molecular phylogenies were evaluated using ClustalW2 at the European Bioinformatics Institute (http://www.ebi.ac.uk). The sequences were deposited in the National Centre for Biotechnology Information (NCBI) gene bank data base

\section{Antagonistic activity of cellular components}

Four types of antimicrobial metabolites, namely, heat killed whole cell product (HKWCP), whole cell product (WCP), intra cellular product (ICP) and extra cellular product (ECP), were prepared from all the four isolates according to Das et al. (2006). Briefly pure cultures of the strains were grown separately in sterile conditions in $250 \mathrm{~mL}$ of brain heart infusion broth (HiMedia, India) at $37^{\circ} \mathrm{C}$ for $24 \mathrm{~h}$. The optical density (OD) of $24 \mathrm{~h}$ old cultures was taken for each bacterium. The $\mathrm{OD}_{546}$ of all the four isolates was adjusted to 0.5 which corresponded to $1.96 \times 10^{6} \mathrm{CFU} \mathrm{mL} \mathrm{mL}^{-1}, 1.6 \times 10^{6} \mathrm{CFU} \mathrm{mL}^{-1}, 1.78 \times 10^{6} \mathrm{CFU} \mathrm{mL}^{-1}$ and $2.17 \times 10^{6} \mathrm{CFU}$ $\mathrm{mL}^{-1}$ for MBTU_PB1, MBTU_PB2, MBTU_PB3 and MBTU_PB4, respectively. The protein estimation of the protein fractions from the isolates was determined according to Bradford (1976). The isolates grown separately in BHI broth were harvested after $24 \mathrm{~h}$ incubation and centrifuged at $12,000 \mathrm{rpm}$ for $10 \mathrm{~min}$ at $4{ }^{\circ} \mathrm{C}$. The bacterial pellets were washed twice and resuspended in phosphate buffered saline (PBS) (pH 7.2) and used as WCP for the antagonistic study. The supernatants obtained after centrifuging $24 \mathrm{~h}$ old cultures of isolates in $\mathrm{BHI}$ broth were filtered $(0.22 \mu \mathrm{m})$. They were further concentrated with $20 \% \mathrm{PEG}$, dialysed against PBS (pH 7.2) and applied as ECP. Each WCP was heat killed at $60^{\circ} \mathrm{C}$ for $1 \mathrm{~h}$ in a water bath and finally stored at $-20{ }^{\circ} \mathrm{C}$ before being employed as HKWCP. The bacterial pellets of the isolated strains were washed twice and resuspended in PBS ( $\mathrm{pH} 7.2$ ), to $2 \%$ of the initial volume. The cell pellets were then sonicated at $50 \mathrm{~Hz}$ for $5 \mathrm{~min}$ (SONICS, VCX-130) filtered through a millipore syringe with a $0.45 \mu \mathrm{m}$ filter and finally stored at $-20{ }^{0} \mathrm{C}$ and used as ICP.

All statistical analyses were carried out using Origin Pro software. The results are expressed as mean \pm standard error.

\section{Treatment of bacteria prior to adhesion}

The four probiotic strains and the five indicator strains were propagated separately in TSB overnight at $37^{\circ} \mathrm{C}$. Bacteria were harvested by centrifugation $(10,000$ $\mathrm{rpm}$, for $10 \mathrm{~min}$ ) at $4^{\circ} \mathrm{C}$ and washed twice with PBS. The optical density of the bacterial suspensions at $600 \mathrm{~nm}$ was adjusted with PBS to $0.5 \pm 0.02$ giving a count that varied between $10^{6}$ and $10^{8} \mathrm{CFUmL}^{-1}$.

\section{Isolation of crude fish mucus}

The fish were starved for $48 \mathrm{~h}$ and the intestines were then removed, transferred to sterile petri dishes and the mucus collected by scrapping the inner intestinal surface with the rubber spatula. The mucus was then homogenized in PBS. All mucus preparations were centrifuged twice at $27000 \mathrm{rpm}$ for $15 \mathrm{~min}$ at $4^{\circ} \mathrm{C}$ to remove the particulate and cellular materials. The mucus suspensions were finally sterilized by UV light exposure or sterilized by filtration through a 0.45 $\mu \mathrm{m}$ filter and stored at $-20^{\circ} \mathrm{C}$ until use.

\section{In vitro adhesion assay}

The crystal violet method was used to determine adhesion ability of the four selected strains and the five indicator strains, separately (Vesterlund et al., 2005) The test cultures were added as a volume of $100 \mu \mathrm{L}$ into micro titer polystyrene plate wells previously coated with $150 \mu \mathrm{L}$ of fish intestinal mucus. The greater volume of the mucus compared to the volume of the added bacteria is used to avoid the contact of the stain with the polystyrene. Bacteria were adhered at $37^{\circ} \mathrm{C}$ for $1 \mathrm{~h}$ and the non adherent bacteria were removed by washing the wells three times with $250 \mu \mathrm{L}$ of PBS. The adherent bacteria were fixed at $60^{\circ} \mathrm{C}$ for $20 \mathrm{~min}$ and stained with crystal violet $(100 \mu \mathrm{L}$ per well, $0.1 \%$ solution) for $45 \mathrm{~min}$. Wells were subsequently washed five times with PBS to remove excess stain. The stain bound to the bacteria was released by adding $100 \mu \mathrm{L}$ of citrate buffer $(\mathrm{pH} 4.3)$. After 45 min incubation at room temperature, the absorbance values at $640 \mathrm{~nm}$ were determined using the micro titer plate reader. Stained mucus without added bacteria was used as negative control. Results were expressed by subtracting the absorbance value of this negative control from absorbance value recorded for all samples according to Vesterlund et al. (2005). Each experiment was performed in triplicate.

\section{Biofilm formation and quantification}

Sample preparation for scanning electron microscopy (SEM) studies was performed as described by Lembke et al. (2006). The biofilms of the four selected isolates on the glass pieces were fixed for $1 \mathrm{~h}$. in a solution containing $2.5 \%$ gluteraldehyde. The glass pieces were washed in $0.1 \mathrm{M}$ sodium acetate buffer ( $\mathrm{pH}$ 7.3). Samples were dehydrated through a graded series of ethanol, dried, coated with platinum and examined using JEOL 6390 (Japan).

The commonly used microtitre-plate method by Rode et al. (2007) was applied in the present study for the quantification of biofilm formation by bacterial strains on polystyrene. Briefly, the wells of sterile 96-well polystyrene microtitre-plates were filled with $230 \mu \mathrm{L}$ of TSB. $20 \mu \mathrm{L}$ cultures of the four selected strains and the five indicator strains were added into each well separately. The negative control wells contained TSB only. The plates were incubated aerobically for $24 \mathrm{~h}$ at tested temperature $\left(37^{\circ} \mathrm{C}\right)$. The content of the microtitre-plates was poured off and the wells were washed three times with $300 \mu \mathrm{L}$ of phosphate buffer. The remaining attached bacteria were fixed with $250 \mu \mathrm{L}$ of methanol per well. After $15 \mathrm{~min}$, microtitre-plates were emptied, air dried and stained with $250 \mu \mathrm{L}$ per well of $1 \%$ crystal violet for $5 \mathrm{~min}$. The excess of stain was rinsed off by placing the microtitre-plates under running tap water. After the microtitre-plates were air dried, the dye bound to the adherent cells was extracted with $250 \mu \mathrm{L}$ of $33 \%$ (v/v) glacial acetic acid per well. The absorbance of each well was measured at $570 \mathrm{~nm}$ using a UV-Vis spectrophotometer. Based on the absorbance $\left(\mathrm{A}_{570}\right)$ produced by the bacterial films, strains were classified into four categories (Christensen et al., 1985; Stepanovic, et al., 2000): $\mathrm{A} \leq \mathrm{A}_{\mathrm{c}}=$ no biofilm producer $(0) ; \mathrm{A}_{\mathrm{c}}<\mathrm{A} \leq\left(2 \mathrm{~A}_{\mathrm{c}}\right)=$ weak biofilm producer $(+) ;\left(2 \mathrm{~A}_{\mathrm{c}}\right)<\mathrm{A} \leq\left(4 \mathrm{~A}_{\mathrm{c}}\right)=$ moderate biofilm producer $(++) ;\left(4 \mathrm{~A}_{c}\right)<\mathrm{A}=$ strong biofilm producer $(+++)$ where the cutoff absorbance $A_{c}$ was the mean absorbance of the negative control. All tests were carried out in triplicate and the results were averaged.

\section{RESULTS AND DISCUSSION}

\section{Antimicrobial activity assay}

Screening of the antagonistic activity of forty six bacterial isolates was carried out against five indicator strains. Thirteen dominant isolates were screened from the above strains on the basis of their similar colony morphology characteristics, gram stain, shape, color, motility. Four bacterial isolates producing maximum inhibition zones against five indicator strains were selected for further identification and probiotic characterization. In this study, the four major isolates showed weak to strong antagonistic activities against the five indicator strains throughout the sampling time. The degree of inhibition varied with respect to the isolate, indicator strain and also the incubation time. Of the forty six isolates, four strains (MBTU_PB1, MBTU_PB2, MBTU_PB3 and MBTU_PB4) showed moderate to strong inhibitory activities against the five indicator strains and these isolates were further selected and identified using $16 \mathrm{~S}$ rDNA gene sequence analysis. MBTU_PB2 and MBTU_PB3 belonged to the genus Staphylococcus, while MBTU_PB1 and MBTU_PB4 belonged to the genera Enterobacter and Acinetobacter, respectively. Normal flora has a well defined role in the immune status of an organism, e.g., more than $10 \%$ of the bacterial isolates from intestinal tract of the fish exhibited antagonistic action (Sugita et al., 1996). This was our motivation to use the organism itself as a source for the isolation of probiotics and the result was promising: primary screening clearly indicated that the thirteen isolated bacterial strains were the major micro flora of guppy. Therefore, we can assume that this major microflora has a well defined role in the immune status of the guppy. Probiotics developed for human use (e.g. Lactobacillus sp.) or for veterinary use (e.g. Bacillus sp.) are being applied for aquatic species too. However, there is a high degree of variability in the outcome since these terrestrial probionts have differential activity in the diverse aquatic environment (Azad and Al-Marzouk, 2008). Therefore, probiotic bacteria isolated from the host environment or from the host itself could be better candidates, as these microorganisms are expected to perform well in their natural milieu.

\section{Identification of isolated strains}

Biochemical tests (VITEK 2) indicated that among the four isolates which showed the highest antimicrobial activities, two were gram-positive cocci, namely,MBTU_PB2 and MBTU_PB3, belonging to the genus Staphylococcus. The remaining two were the gram-negative rods, namely, MBTU_PB1 (genus Enterobacter) and MBTU_PB4 (genus Acinetobacter). The results for the identification of the isolates obtained from the biochemical tests were further confirmed by $16 \mathrm{~S}$ rDNA gene sequencing (NCBI GenBank accession numbers JN247799, JN247800, JN247801 and JN247802 for MBTU_PB4, MBTU_PB3, MBTU_PB1 and MBTU_PB2, respectively). 


\section{Protein estimation of different cellular components of isolated strains}

The protein contents of ICP, WCP, HKWCP and ECP from the isolates are given in Table 1. Among the different cellular components of all the strains, the ICP of MBTU_PB4 contains the highest protein concentration $\left(41.2 \mu \mathrm{g} \mathrm{mL}^{-1}\right)$ and the lowest protein content is observed in the ECP of MBTU_PB2 $\left(5.2 \mu \mathrm{g} / \mathrm{mL}^{-1}\right)$.

Table 1Protein estimation

\begin{tabular}{lcccc}
\hline \multirow{2}{*}{$\begin{array}{l}\text { Bacterial } \\
\text { isolates }\end{array}$} & \multicolumn{5}{c}{ Concentration of cellular components $\left(\boldsymbol{\mu g} \mathbf{~ m L}^{-\mathbf{1}}\right)$} \\
\cline { 2 - 5 } MBTU_PB1 & WCP & ECP & HKWCP & ICP \\
\hline MBTU_PB2 & 6.4 & 11.5 & 6.0 & 16.7 \\
\hline MBTU_PB3 & 25.3 & 5.2 & 29.1 & 38.9 \\
\hline MBTU_PB4 & 8.6 & 38.5 & 8.2 & 30.5 \\
\hline
\end{tabular}

Heat killed whole cell product -HKWCP, whole cell product -WCP, intra cellular product ICP and extra cellular product - ECP

\section{Biocontrol study using cellular components of isolated strains}

Results obtained from the WCP, HKWCP, ECP and ICP of the four isolated strains against the five indicator strains are shown in Fig 1. The WCP of each isolate showed no inhibitory activity against all the investigated indicator strains, as compared to PBS control $(0 \mathrm{~mm})$. The results also revealed that among the different cellular components, the ECP of each isolated strain was found to be highly effective and produced a zone ranging from approximately 18 to $35 \mathrm{~mm}$ against all the five indicator strains. The highest recorded inhibition zones for the HKWCP samples were observed by the three selected strains against Alcaligenes $(26 \mathrm{~mm} \pm 0.7 \mathrm{~mm}, 22 \mathrm{~mm} \pm 0.6 \mathrm{~mm}$ and $26 \mathrm{~mm} \pm 0.3 \mathrm{~mm}$ for MBTU_PB1,MBTU_PB2 and MBTU_PB3, respectively), while MBTU_PB4 showed the highest zone of inhibition for the HKWCP with Flavobacterium (24 $\mathrm{mm} \pm 0.3 \mathrm{~mm}$ ). Of the three cellular products (HKWCP, ECP and ICP), the ICP produced the lowest activity in almost all cases.

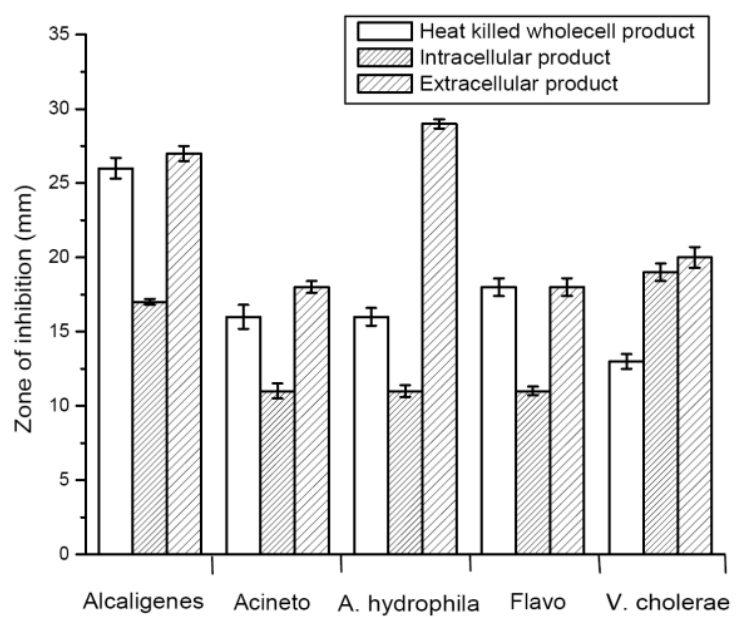

(a)

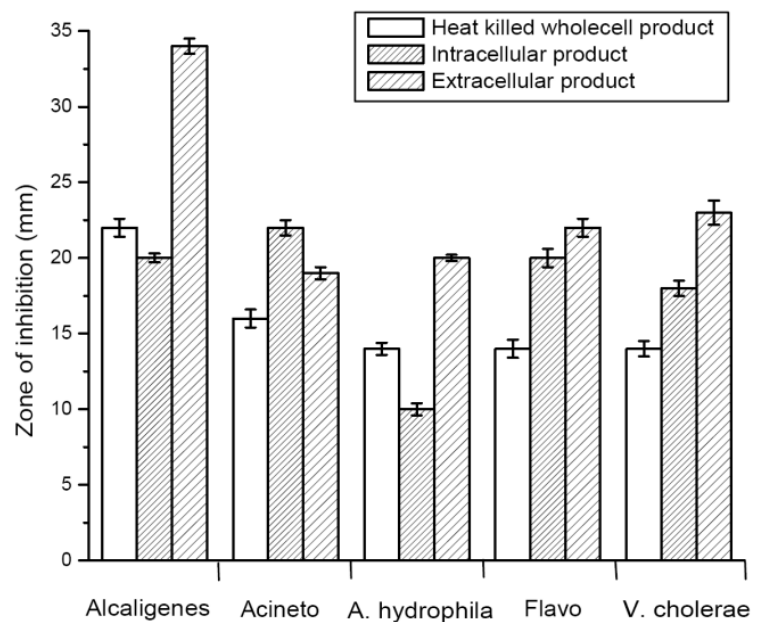

(b)

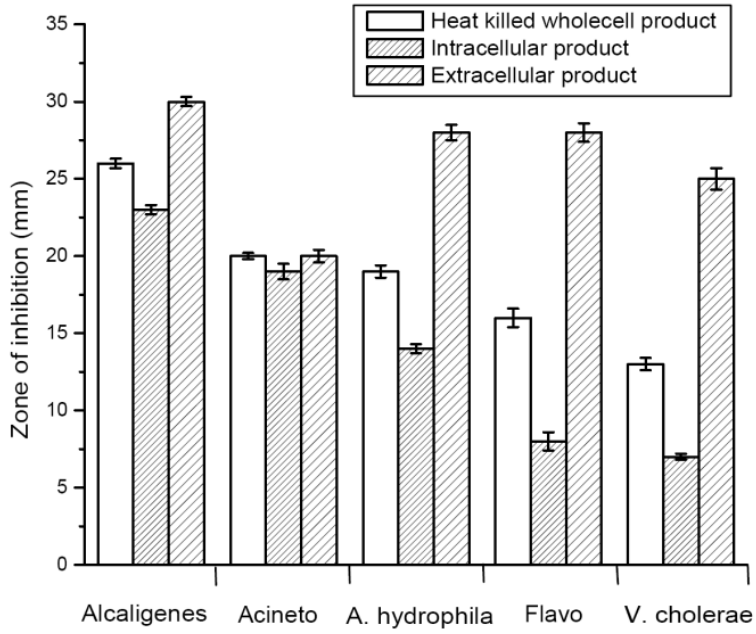

(c)

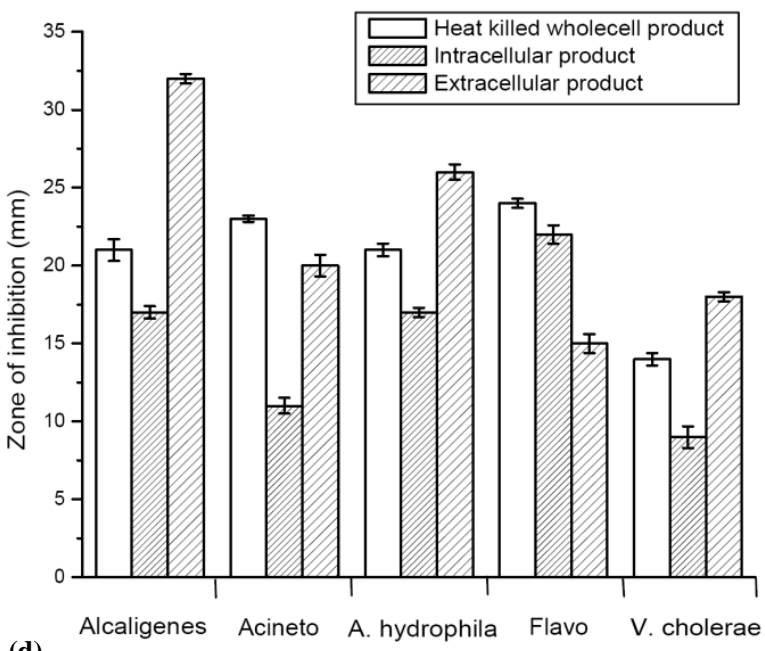

(d)

Figure 1 Zones of inhibition of cellular components of (a) MBTU PB1,(b) MBTU_PB2, (c) MBTU_PB3 and (d) MBTU_PB4 against five indicator strains. Values are represented as mean \pm standard error

The characteristics of the selected four bacterial isolates were relevant for the biological control of the five indicator strains. The antibacterial effect of bacteria is generally due to either individual or joint production of antibiotics, bacteriocins, siderophores, lysozymes and proteases and alteration of $\mathrm{pH}$ by organic acid production. The inhibition due to such compounds is highly dependent on the experimental conditions, which are different in vitro and in vivo. It has been suggested that the effect can be dependent on the assay conditions, such as the amount and purity of bacteriocin, culture media, indicator strain and its cellular concentration (Das et al., 2006). A probiotic mixture was more effective than applying a single species. Additionally, the complementary responses to pathogens were desirable because each bacterial strain can assume a different niche for an effective response (Salinas et al., 2005). The study of the effect of cellular components of the selected four strains against the indicator strains showed that the WCP of each isolate had no inhibitory activity against the tested indicator strains. The HKWCP, ECP and ICP components of the four isolates were effective, as revealed by the zone of inhibitions to all the tested indicator strains. Of these three, ECP and HKWCP were equally effective showing maximum inhibition towards all the indicator strains. We observed no association between protein contents of different cellular components and their zone of inhibition toward pathogens. The cellular components of lactic acid bacteria are reported to have the ability to inhibit the growth of various fish pathogens in vitro conditions (Verschuere et al., 2000). Hence, lactic acid bacterial strains can be considered a very promising alternative to the use of chemotherapeutic agents (Verschuere et al., 2000). Giri et al. (2011) characterized the antagonistic activity of cellular components of potential probiotic bacteria isolated from the gut of healthy rohu (Labeo rohita), a tropical freshwater fish, against the fish pathogen, Aeromonas hydrophila. Due to the increase in therapeutic resistance to the more commonly used antibiotics and the anti-pathogenic (Del et al., 1998) actions of the cellular products, there appears to be a potential for the selected four isolates in the control of aquaculture diseases in fishes, particularly against the tested indicator strains. Further assays are necessary to characterize the anti-pathogenic metabolites excreted by these 
selected four isolates. There were many reports of antimicrobial properties of normal flora (Lee et al., 2001).

\section{In vitro adhesion assay}

The four selected strains and the five indicator strains were tested for their ability to adhere to intestinal fish mucus. The results revealed differences in adhesion among both the isolates and the indicator strains. The selected isolates al competed and adhered more than the indicator strains, which significantly showed poor adhesion to the intestinal mucus. Among the isolated strains, MBTU_PB4 $\left(\mathrm{OD}_{640}=0.56 \pm 0.03\right)$ was found to adhere significantly better than all the other isolated strains, while Vibrio cholera $\left(\mathrm{OD}_{640}=0.21 \pm 0.02\right)$ showed better adhesion ability compared to the other four indicator strains. The ability to adhere to epithelial cells and mucosal surfaces to reduce or prevent colonization of pathogens has been suggested to be an important property of many bacterial strains used as probiotics (Vine $\boldsymbol{e t}$ al., 2004b). Cell adhesion is a complex process involving contact between the bacterial cell membrane and interacting surfaces Several researchers have reported investigations on composition, structure and forces of interaction related to bacterial adhesion to intestinal epithelial cells and mucus (Del et al., 1998; Pérez et al., 1998). In addition, adhesion-promoting proteins, which are present on the cell surface of Lactobacillus fermentum and Lactobacillus brevis have been isolated and characterized (Rojas et al., 2002).All of the four selected isolates competed and adhered more than the tested indicator strains which significantly showed poor adhesion to the intestinal mucus. Among the isolated strains, MBTU_PB4 adhered significantly better than all the other isolated strains, while Vibrio showed better adhesion ability when compared to the other four indicator strains. The mechanism of adhesion is not studied here, and remains unclear. Servin and Coconnier (1993) showed that the lactobacilli adhesion process included passive forces, electrostatic interaction, hydrophobic and steric forces. It has been reported that lipoteichoic acids are one of the factors responsible for adhesion of Lactobacillus johnsonii LaI (Granatoet al., 1999).

\section{Biofilm formation and quantification}

SEM studies were performed to elucidate the potential of the four selected strains to form biofilms. Scanning electron micrographs revealed dense biofilm formations (see Fig 2) on the surface of the glass pieces by three of the isolated strains MBTU_PB2, MBTU_PB3 and MBTU_PB4.

At the optimum growth temperature $\left(37^{\circ} \mathrm{C}\right), \mathrm{MBTU}$ PB3 had the maximum ability to form biofilm, while MBTU_PB2 and MBTU_PB4 displayed moderate biofilm productions. MBTU_PB1 showed the weakest ability to form biofilm among the selected isolates. These results are in good agreement with the SEM analysis. Similar behavior was obtained for indicator strains where $V$. cholerae, Flavobacterium and Alcaligenes being the highest biofilm producers (+++), while A. hydrophila and Acinetobacter showed moderate biofilm productions at their optimum growth temperature $\left(37^{\circ} \mathrm{C}\right)$.

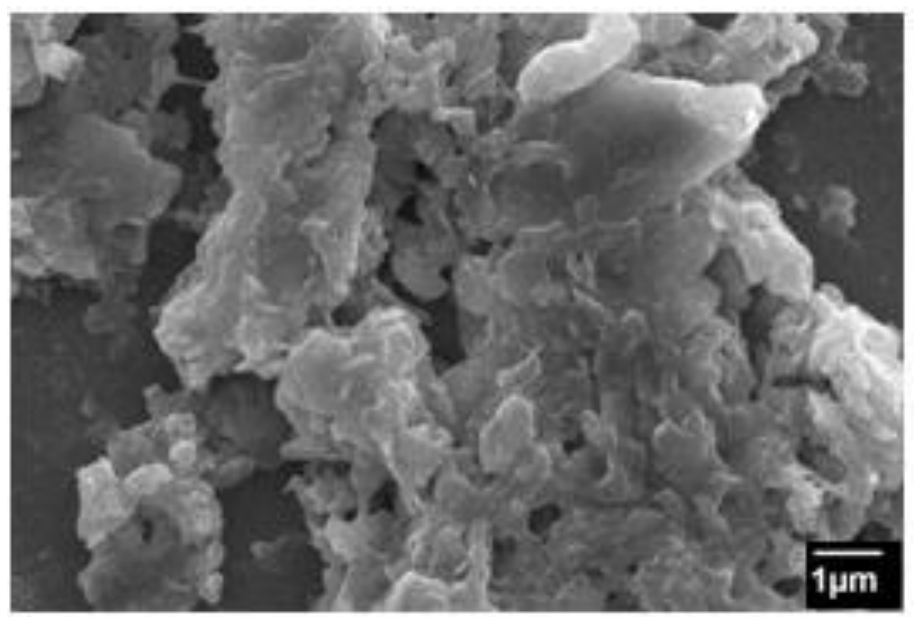

Figure 2 Scanning electron micrographs of biofilm formed by MBTU_PB3 on the glass surface

In nature, the bulk of bacterial biomass is believed to exist as an adherent community of cells called a biofilm (de Kievit, 2009). Roseobacter 27-4 formed biofilms, which facilitated its production of an antibacterial compound, tropodithietic acid (TDA) (Bruhn et al., 2005). The combination of forming both rosette and biofilm and producing TDA may be optimal for a probiotic bacterium. The present investigation indicated dense biofilm formations by the three selected strains (MBTU_PB2, MBTU_PB3 and MBTU_PB4). Quantitative analysis of the biofilm production showed that, of these selected strains (at identical conditions), MBTU_PB3 had the highest ability to form biofilm.

\section{CONCLUSION}

The investigation has demonstrated the in vitro antagonistic activity in isolated strains of guppy. The main application of these probiotic strains would be to exploit their benefits by limiting the appearance of pathogenic bacteria in freshwater aquaculture systems. Today, aquaculture sector face constraints in maintenance of proper culture conditions especially due to disease outbreaks, nutritional status and water quality. Probiotic therapy can manage these problems very effectively. The antagonistic activity proposed in our study has to be confirmed in future in vivo experiments and this novel probionts needs to be chemically characterized for their anti-bacterial compounds.

Acknowledgements: The first author gratefully acknowledges Dr. Keerthi T. R., Mahatma Gandhi University, for useful discussions, and financial support from the University Grants Commission, Government of India, New Delhi, under grant UGC-F.No.37-264/2009 (SR)

\section{REFERENCES}

AUSTIN, B., STUCKEY, L.F., ROBERTSON, P.A.W., EFFENDI, I., GRIFFITH, D. 1995. A probiotic strain of Vibrio alginolyticus effective in reducing diseases caused by Aeromonas salmonicida, Vibrio anguillarum and Vibrio oratii. Journal of Fish diseases, 18, 93-96. http://dx.doi.org/10.1111/j.1365-2761.1995.tb01271.x

AZAD, I.S., AL-MARZOUK, A. 2008, Autochthonous aquaculture probiotics - a critical analysis. Res. J. Biotech., 3, 171-177.

BALAKRISHNA, A., KEERTHI, T.R. 2012. Screening of potential aquatic probiotics from the major microflora of guppies (Poecilia reticulata), Frontier of Chemical Science and Engineering, 6 (2), 163-173. http://dx.doi.org/10.1007/s11705-012-1283-4

BALAKRISHNA, A., KUMAR, N. A. 2012. Preliminary studies on siderophore production and probiotic effect of bacteria associated with the Guppy, Poecilia reticulata Peters, 1859. Asian Fisheries Science, 25 (2), 193-205.

BALAKRISHNA A, 2013. In vitro Evaluation of Adhesion and Aggregation Abilities of Four Potential Probiotic Strains Isolated from Guppy (Poecilia reticulata). Brazilian Archives of Biology and Technology, 56 (5) 793-800. http://dx.doi.org/10.1590/s1516-89132013000500010

BALCAZAR, J.L., DE BLAS, I., RUIZ-ZARZUELA, I., VENDRELL, D., MUZQUIZ, J. L. 2004. Probiotics: a tool for the future of fish and shellfish health management. Journal of Aquaculture in the Tropics, 19, 239-242.

BRADFORD, M. 1976. A rapid and sensitive method for the quantification of microgram quantities of protein utilizing the principle dye binding. Analytical Biochemistry, 72, 248-254. http://dx.doi.org/10.1006/abio.1976.9999

BRUUN, M.S., SCHMIDT, A.S., MADSEN, L., DALSGAARD, I. 2000 Antimicrobial resistance patterns in Danish isolates of Flavobacterium psychrophilum. Aquaculture, 187, 201-212. http://dx.doi.org/10.1016/s00448486(00)00310-0

CHARACKLIS, W.G., MARSHALL, K.C. 1990. Biofilms: a basis for an interdisciplinary approach. In: Characklis W.G., Marshall K.C. (Eds) Biofilms. John Wiley and Son, New York NY pp. 3-15.

CHRISTENSEN, G.D., SIMPSON, W.A., YOUNGER, J.J., BADDOUR, L.M., BARRETT, F.F., MELTON, D.M. BEACHEY, E.H. 1985. Adherence of coagulase-negative staphylococci to plastic tissue culture plates: A quantitative model for the adherence of staphylococci to medical devices. Journal of clinical Microbiology, 22, 996-1006.

DAS, B.K., SAMAL, S.K., SAMANTARAY, B.R., SETHI, S., PATTNAIK, P., MISHRA, B.K. 2006. Antagonistic activity of cellular components of Pseudomonas species against Aeromonas hydrophila. Aquaculture, 253, 17-24. http://dx.doi.org/10.1016/j.aquaculture.2005.01.028

deKIEVIT, T.R. 2009. Quorum sensing in Pseudomonas aeruginosa biofilms. Environmental Microbiology, 11(2), 279-288. http://dx.doi.org/10.1111/i.14622920.2008.01792.x

DEL RE B., BUSETTO A., VIGNOLA G., SGORBATI B., PALENZONA D. 1998.Autoaggregation and adhesion ability in a Bifidobacterium suis strain. Letters in Applied Microbiology, 27, 307-310. http://dx.doi.org/10.1046/j.1472765x.1998.00422.x

FULLER, R. 1989 A review: Probiotics in man and animals. Journal of Applied Bacteriology 66, 365-378. http://dx.doi.org/10.1111/j.1365-2672.1989.tb05105.x GIRI, S.S., SUKUMARAN, V., SEN, S.S., VINUMONIA, J., BANU, B.N., JENA, P.K. 2011. Antagonistic activity of cellular components of potential probiotic bacteria, isolated from the gut of Labeo rohita, against Aeromonas hydrophila. Probiotics and Antimicrobial Proteins, 3(3-4), 214-222. http://dx.doi.org/10.1007/s12602-011-9078-3

GRANATO, D., PEROTTI, F., MASSEREY, I., ROUVET, M., GOLLIARD, M., SERVIN, A. BRASSART, D. 1999. Cell surface-associated lipoteichoic acid acts as an adhesion factor for attachment of Lactobacillus johnsonii LaI to human enterocyte-like Caco-2 cells. Appl. Environ. Microbiol., 65, 1071-1077.

LEE, K. H., JUN, K.D., KIM W.S., PAIK, H.D. 2001. Partial characterization of polyfermenticin SCD, a newly identified bacteriocine of Bacillus polyfermenticus. 
Letters in Applied Microbiology, 32, 146- 151. http://dx.doi.org/10.1046/j.1472765x.2001.00876.x

LEMBKE, C., PODBIELSKI, A., HIDALGO-GRASS, C., JONAS, L., HANSKI, E., KREIKEMEYER, B. 2006.Characterization of biofilm formation by clinically relevant serotypes of group A streptococci. Applied and Environmental Microbiology, 72, 2864-2875. http://dx.doi.org/10.1128/aem.72.4.28642875.2006

OUWEHAND, A.C., KIRJAVAINEN, P.V., GRONLUND, M.M., ISOLAURI, E. SALMINEN, S.J. 1999 Adhesion of probiotic micro-organisms to intestinal mucus. International Dairy Journal, 9, 623-630. http://dx.doi.org/10.1016/s0958. 6946(99)00132-6

PÉREZ, P.F., MINNAARD, Y., DISALVO, E.A., DE ANTONI , G.L. 1998. Surface properties of bifidobacterial strains of human origin. Applied and Environmental Microbiology, 64, 21-26.

RODE, T.M., LANGSRUD, S., HOLCK, A., MØRETRØ, T. 2007. Different patterns of biofilm formation in Staphylococcus aureus under food- related stress conditions. International Journal of Food Microbiology, 116, 372-383. http://dx.doi.org/10.1016/j.ijfoodmicro.2007.02.017

ROJAS, M., ASCENCIO, F.,CONWAY, P.L. 2002. Purification and characterization of a surface protein from Lactobacillus fermentum 104R that binds to porcine small intestinal mucus and gastric mucin. Appl. Environ. Microbiol., 68, 2330-2336. http://dx.doi.org/10.1128/aem.68.5.2330-2336.2002

SALINAS, I., CUESTA, A., ESTEBAN, M.A., MESEGUER, J. 2005. Dietary administration of Lactobacillus delbrueckii and Bacillussubtilis, single or combined, on gilthead seabream cellular innate immune responses. Fish Shellfish Immunology, 19(1), 67-77. http://dx.doi.org/10.1016/i.fsi.2004.11.007

SAMBROOK, J., FRITSCH E, F., MANIATIS, T. 1989. Molecular cloning: a laboratory manual, 2nd ed. Cold Spring Harbor Laboratory, Cold Spring Harbor, NY

SERVIN, A.L., COCONNIER, M.H. 2003. Adhesion of probiotic strains to the intestinal mucosa and interaction with pathogens. Best Pract. Res. Clin. Gastroenterol., 17, 741-754. http://dx.doi.org/10.1016/s1521-6918(03)00052-0

STEPANOVIC, S.D., VUKOVIC, L.B., DAKICSAVIC, M., SVABICVLAHOVIC. 2000. A modified microtiter-plate test for quantification of staphylococcal biofilm formation. Journal of Microbiological Methods, 40, 175179. http://dx.doi.org/10.1016/s0167-7012(00)00122-6

SUGITA, H., MATSUO, N., SHIBUYA, K., DEGUCHI, Y. 1996. Production of antibacterial substances by intestinal bacteria isolated from coastel crab and fish species. J. Mar. Biotechnol., 4, 220-223.

VERSCHUERE, L., ROMBAUT, G., SORGELOOS, P., VERSTRAETE, W. 2000. Probiotic bacteria as biological control agents in aquaculture. Micobiology and Molecular Biology Reviews, 64, 655-671. http://dx.doi.org/10.1128/mmbr.64.4.655-671.2000

VESTERLUND, S., PALTTA, J., KARP, M., OUWEHAND, A.C. 2005 Measurement of bacterial adhesion, in vitro evaluation of different methods. Journal $\begin{array}{llll}\text { of Microbiological } & \text { Methods, } & 60, & \end{array}$ http://dx.doi.org/10.1016/j.mimet.2004.09.013

VINE, N.G., LEUKES, W.D., KAISER, H., DAYA, S., BAXTER, J., HECHT, T.

2004B. Competition for attachment of aquaculture candidate probiotic and pathogenic bacteria on fish intestinal mucus. Journal of Fish Diseases, 27, 319

326. http://dx.doi.org/10.1111/j.1365-2761.2004.00542.x 